\title{
STUDY OF THE INFLUENCE OF GEOTEXTILE MATERIALS DURING CONSTRUCTION OF DAMS
}

\author{
${ }^{1}$ Slobodianyk H.V., Ph.D., \\ annaslobodyanik27@gmail.com, ORCID: 0000-0001-6437-0033 \\ ${ }^{1}$ Shokot K.Z., master, \\ karina10023017@gmail.com, ORCID: 0000-0002-4316-4465 \\ ${ }^{1}$ Odessa National Maritime University \\ 34, Mechnikova st., Odessa, 65029, Ukraine
}

\begin{abstract}
One of the real and promising ways to expand the range and types of structures for strengthening the slopes of embankments and dams is the use of geotextile materials. In the structures under consideration, they can perform protective, filtering, separating, reinforcing functions and moreover they improve the working conditions of the soil and layers of road pavements on the sides of the road and in the slope parts, increasing their stability. The use of geotextiles makes it possible to develop technically and economically effective design solutions.

As the analysis of literature data has shown, soil reinforcement is an effective method for increasing the bearing capacity of foundations at a relatively low cost. Therefore, research, both theoretical and experimental, the development and creation of computational models taking into account the influence of reinforcing elements is an urgent problem.

The paper considers the stress-strain state of a bulk dam without and with two options for the location of geotextiles. On the basis of the carried out numerical modeling, it is shown how when using geotextiles, the bearing capacity of a structure increases, while the volume of materials decreases. At the second stage, on the basis of the calculations, the optimal variant of the location of the geotextile material in the body of the structure was selected with the best technical and economic indicators.

The research results show that when reinforcing the embankment with open clips in two rows - in the upper and lower parts-the smallest horizontal and vertical movements are obtained at almost the same total stresses. At the same time, the required value of the resistance coefficient is achieved, and the volume of soil is reduced.

Thus, it can be concluded that the use of geotextile materials can reduce the cost of basic building materials while increasing operational characteristics and extending the service life of the structure.
\end{abstract}

Keywords: bulk dam, geotextile, soil reinforcement, slope stability.

Introduction. The construction of new roads and the development of new territories are very closely linked to each other. When tracking roads to provide allowable slopes, as well as overcoming obstacles on the terrain, the earthen canvas is executed in the form of embankments, slots or dams.

Engineering practice of strengthening the slips and dams constantly requires improvements to existing structural and technological solutions in this area. This is caused by two reasons. One of them is the absence of lightweight structures that occupy an intermediate position between the grass and powerful strengthening of the slabs or a stone cape.

Another reason is due to the necessity of industrialization of structures of strengthening, reducing the volume of work performed on the slope. The fact is that the work of people and mechanisms on the slope is extremely complicated, there is no compacted soil. As a result, the quality of fortifications is low, and the construction of a number of structures on the slopes with laying 1:1.5-1:2 is often in general. All this causes defects, especially in rigid structures, whose general work is difficult to provide. In such conditions, a flexible design could be more stable because of the ability to adapt to the deformation of the surface of the slope.

One of the real and promising ways of expanding the nomenclature and species of structures of strengthening slopes and the road is the use of geotextile materials that have become widespread

Bulletin of Odessa State Academy of Civil Engineering and Architecture, 2021, no. 83, page 112-121 
in recent years. Fulfilling a reinforcing, draining, filtering functions, geotextile cloths improve the conditions of soil and grain layers on the roads, in the load parts of embroidery and slots, increasing their stability, protecting them, preventing a supersonal process. The use of geotextiles makes it possible to develop new, more efficient in technical and economic constructive decisions.

Analysis of literary data and problem statement. Synthetic materials in construction are used to create additional layers (separating, draining, filtering, protective, reinforcement) when arranging road bases for further asphalt, in drainage structures and structures of surface drainage, with the strengthening of slopes of embryos and slots of excavations and etc. [1-4].

In works [5-9], the authors provide the strengthening of the soil web with bulk elements and the results of experimental studies to determine the dependencies of the mechanical characteristics of the reinforced medium from reinforcement parameters.

In works [10-12] the use of geosynthetic materials in road construction, and also the results of research on the application of finite elements (ISI) for modeling the work of an arm-based basis, are considered.

The article [13] presents the results of the development of new methods for assessing the stress-deformed state of the system of "construction-base" based on the ITS taking into account reinforcing elements.

In the article [14], the results of theoretical and experimental studies of flexible fasteners of the slopes of earthen hydraulic structures are given with using geotextiles. Also there are considered of the calculation schemes of the stability of flexible fasteners from rock caps and concrete blocks, which are flexible connections.

The literary data illustrated that soil reinforcement is an effective method for increasing the bearing capacity of the bases at relatively small costs. Therefore, both theoretical and experimental researches, development and creation of settlement models, taking into account the influence of reinforcement elements, are an urgent problem.

Goal and research tasks. The country development depends on the quality of roads and the master of new territories. When traced roads to overcome obstacles, the earthen canvas is executed in the form of embankments, slots or dams. Strengthening data of structures through geotextile materials will lead to a collaborative work of soil and increasing the bearing capacity of the base. The use of geotextiles makes it possible to develop new, more efficient technical and economic terms. Constructive decisions. bulk dam.

The purpose of the work is the influence of geotextile materials on the stability of slopes of a

When achieving the goal, you need to solve the following tasks:

- to conduct a study of the general stability of the bulk dam with the use of geotextile materials;

- to conduct a comparative analysis of the results and evaluate the economic efficiency of the use of geotextiles.

Materials and methods of research. In the work, three cases were considered - a bulk dike when laying slopes 1:1, 1:1.5, 1:2. Height of embankment $7 \mathrm{~m}$, the width of the floor $-10 \mathrm{~m}$ (Fig. 1). The load from its own weight of the body of embankment and road clothing was taken into account.

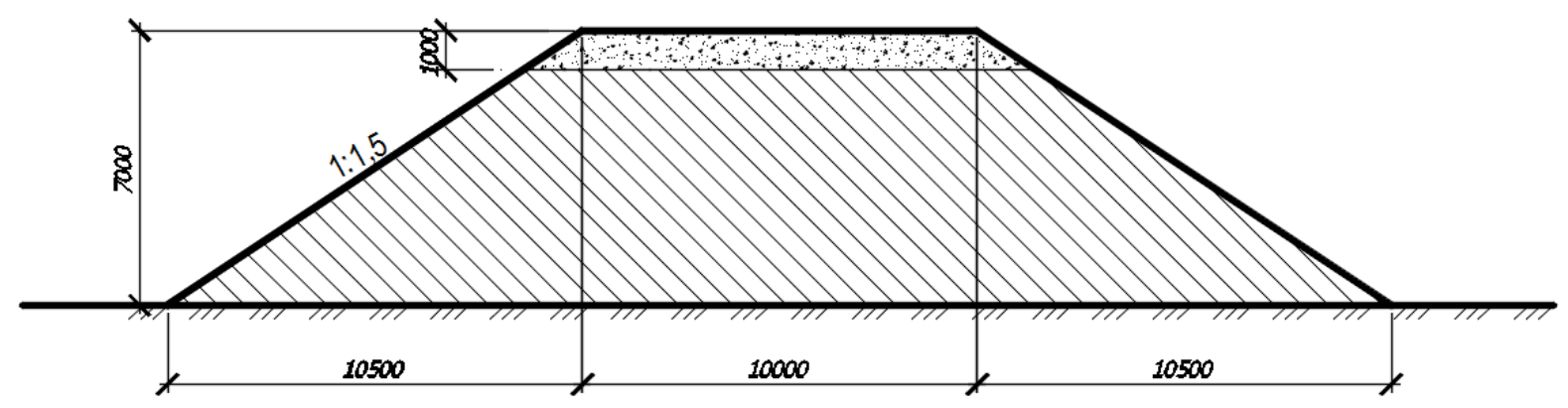

Fig. 1. Bulk damba 
The calculation of general stability was carried out by the method of round cylindrical surfaces of sliding.

The reinforcement of bulk dam geotextile allows you to increase the overall stability. In this paper, it is proposed to use geotextile material with minimal stretching strength $R_{P}=70 \mathrm{~N} / \mathrm{cm}$ and thickness $\delta=4 \mathrm{~mm}$.

For reinforcement of geotextile material, the following parameters $[2,4]$ must be calculated in the use of the bulk dam [2, 4]:

- number of layers;

- length of laying a layer;

- distribution of layers by the height of the embankment.

The calculation of these parameters is based on the method of BSN 49-86 [4].

Also, the study of the stress-deformed state of the bulk dam was considered in Plaxis [15]. 3 cases were considered when laying 1:1.5. In this instance, it was considered:

- bulk dam (Fig. 2, a);

- bulk dam with two layers of geotextiles in the form of unfinished clips (Fig. 2, b);

- a bulk dike with the reinforcement of the embankment (Fig. 2, c).

a)

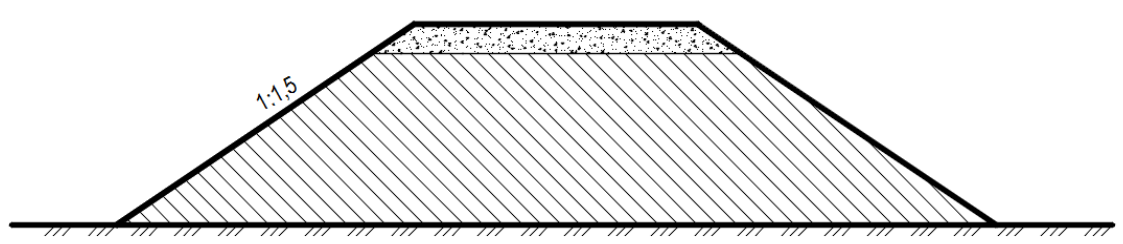

b)

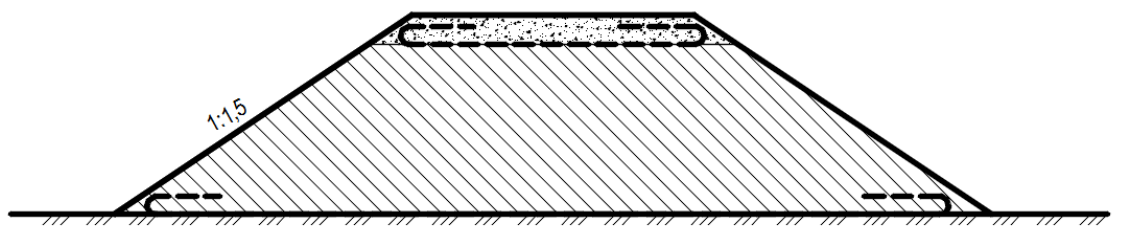

c)

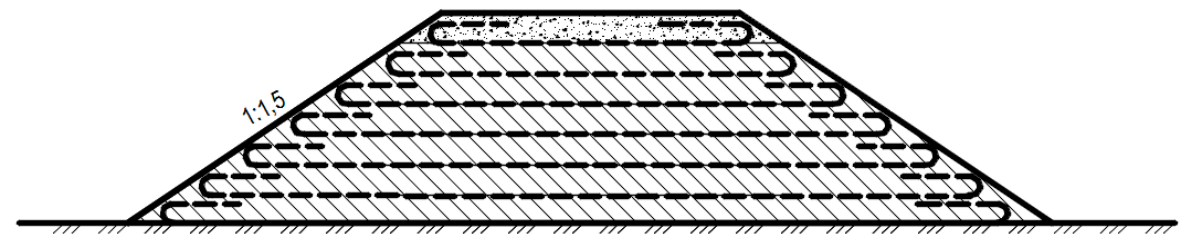

Fig. 2. A bulk dams:

$\mathrm{a}$ - without geotextiles; $\mathrm{b}$ - two layers of geotextiles; $\mathrm{c}$ - reinforcement geotextile

The calculations were performed in several stages, characterizing the stages of construction of the construction. To match the influence of geotextiles on the stress-deformed state of the railway, there have been made the calculations for embankment without geotextiles and calculations of mold with geotextile, and also there have been investigated the total stability of the structure. At the first stage, the stress-deformed state of its own soil weight is determined. On the second - the stressdeformed state of the road embankment from the action of its own weight of the soil, the third determined the stability of the displacement.

Soils of the base consist of three layers with the following indicators of physical-mechanical properties: grip c $\left(\mathrm{kN} / \mathrm{m}^{2}\right)$, an angle of internal friction $\varphi$ (in degrees), deformation module $\mathrm{E}\left(\mathrm{kN} / \mathrm{m}^{2}\right)$ and the Poisson coefficient (dimensionless value). The soil layers are arranged from top to bottom:

- first layer $-\gamma=17.2 \mathrm{kN} / \mathrm{m}^{3}, \mathrm{c}=20, \varphi=18, \mathrm{E}=16000, \mu=0.35$;

- the second layer $-\gamma=18.6 \mathrm{kN} / \mathrm{m}^{3}, \mathrm{c}=21, \varphi=24, \mathrm{E}=9000, \mu=0.30$;

- the third layer $-\gamma=16.8 \mathrm{kN} / \mathrm{m}^{3}, \mathrm{c}=14, \varphi=22, \mathrm{E}=26000, \mu=0.30$. 
The soils that make up the embankment have the following characteristics:

- the upper layer $-\gamma=18 \mathrm{kN} / \mathrm{m}^{3} ; \mathrm{c}=0, \varphi=28, \mathrm{E}=28000, \mu=0.3$;

- the body of the embankment $-\gamma=19 \mathrm{kN} / \mathrm{m}^{3} ; \mathrm{c}=4, \varphi=24, \mathrm{E}=22000, \mu=0.3$.

The results are presented in the form of EPUs in Fig. 3-14.

1 stage of calculations - an existing embankment.

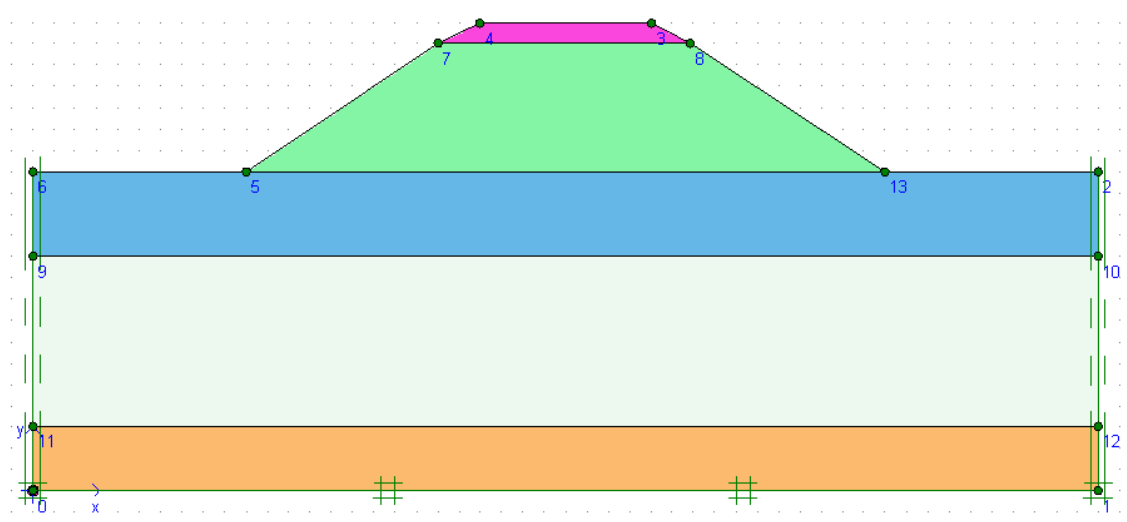

Fig. 3. Estimated scheme

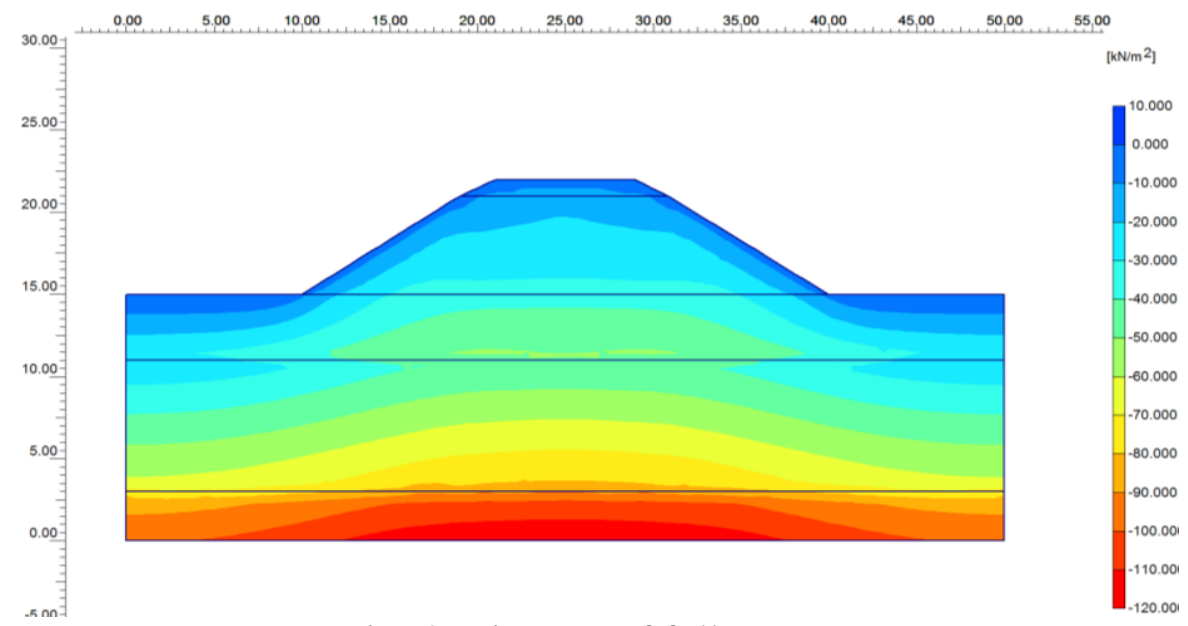

Fig. 4. Diagram of full stresses

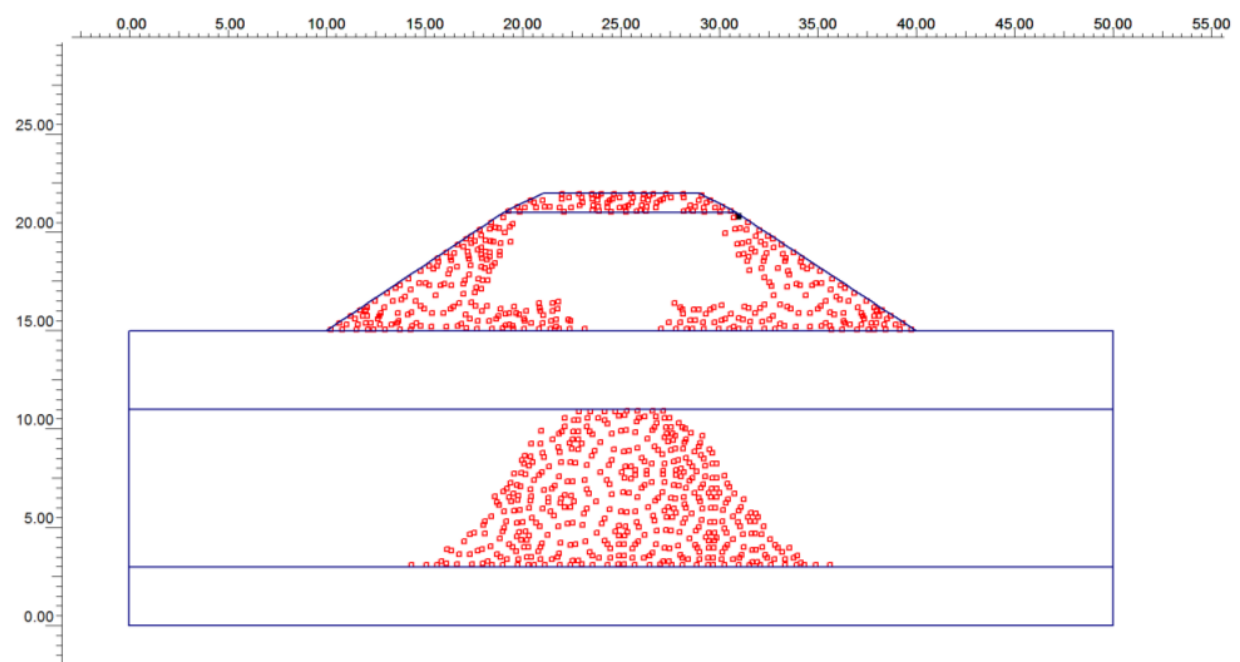

Fig. 5. Scheme of emerging plastic zones

The following diagrams were obtained by calculating the stability. The coefficient of stability is obtained 1.356 . 


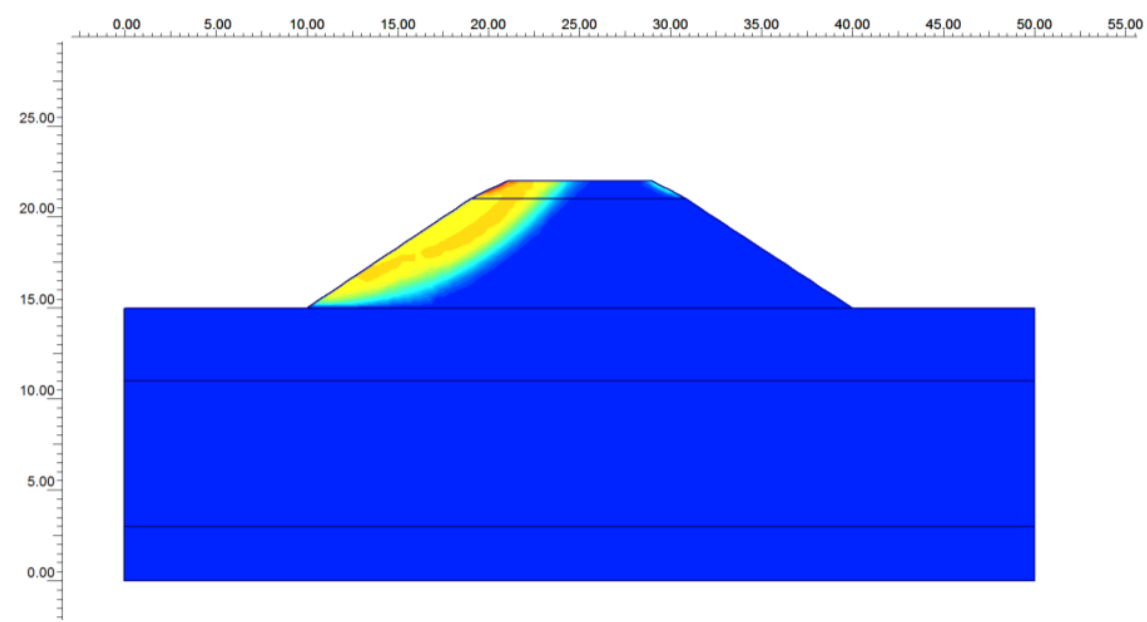

Fig. 6. General displacement

Results of calculations when using geotextiles.

Geotextile stacked in the upper and lower parts in two levels. There is top at a distance of $1 \mathrm{~m}$ from the surface and along the boundary of the embankment. In this case, it is imperative to indicate the pinching of geotextile material in the soil of the embankment.

2 Case - geotextile is located two layers of open clips.

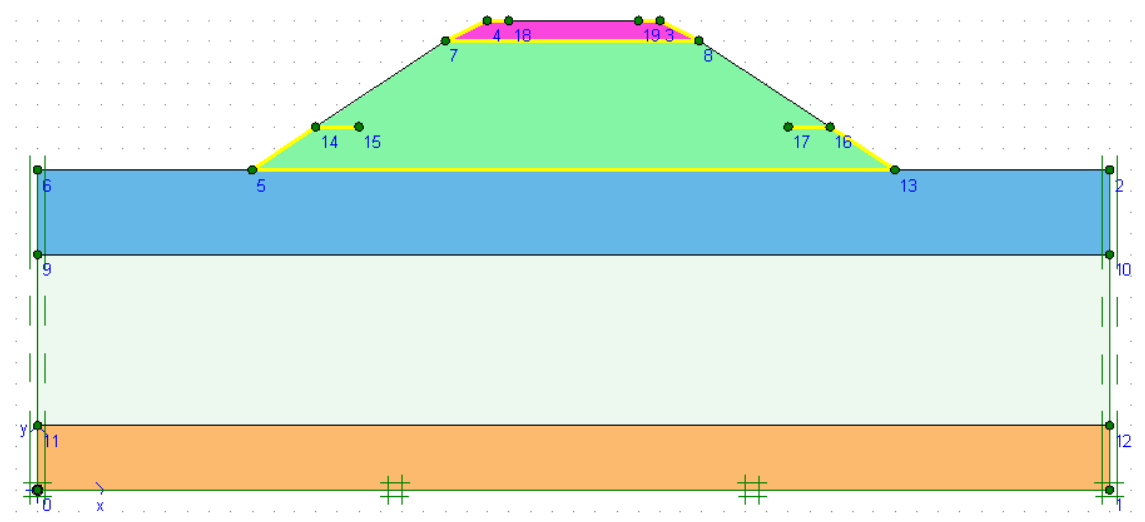

Fig. 7. Estimated scheme

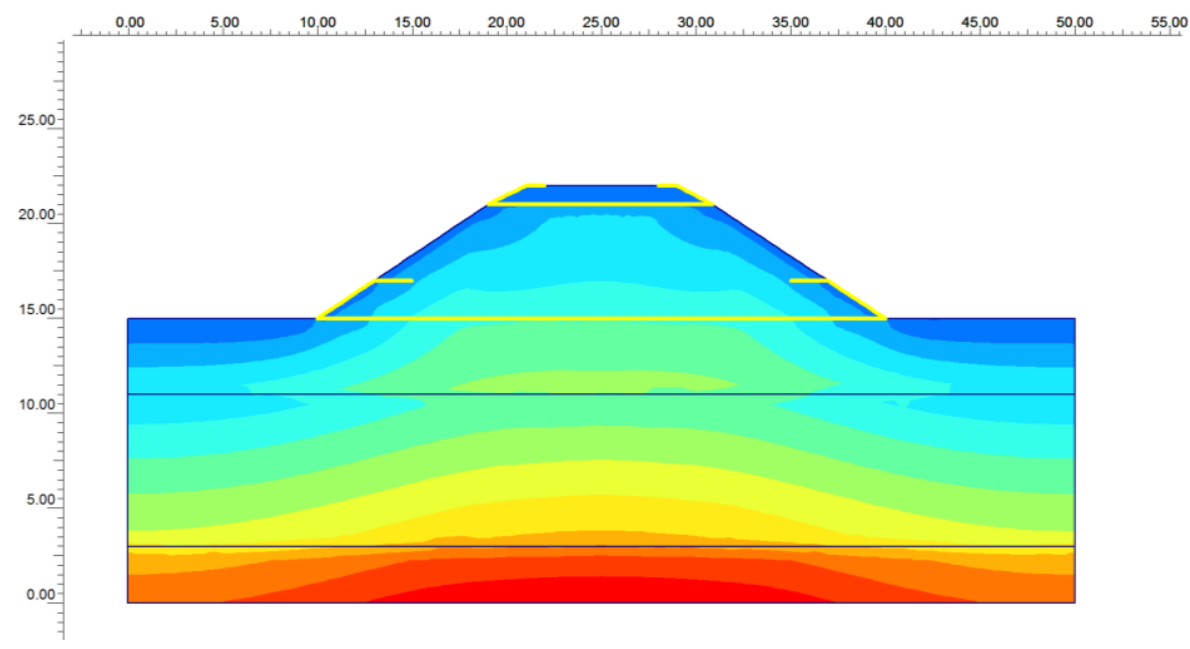

Fig. 8. Diagram of full stresses 


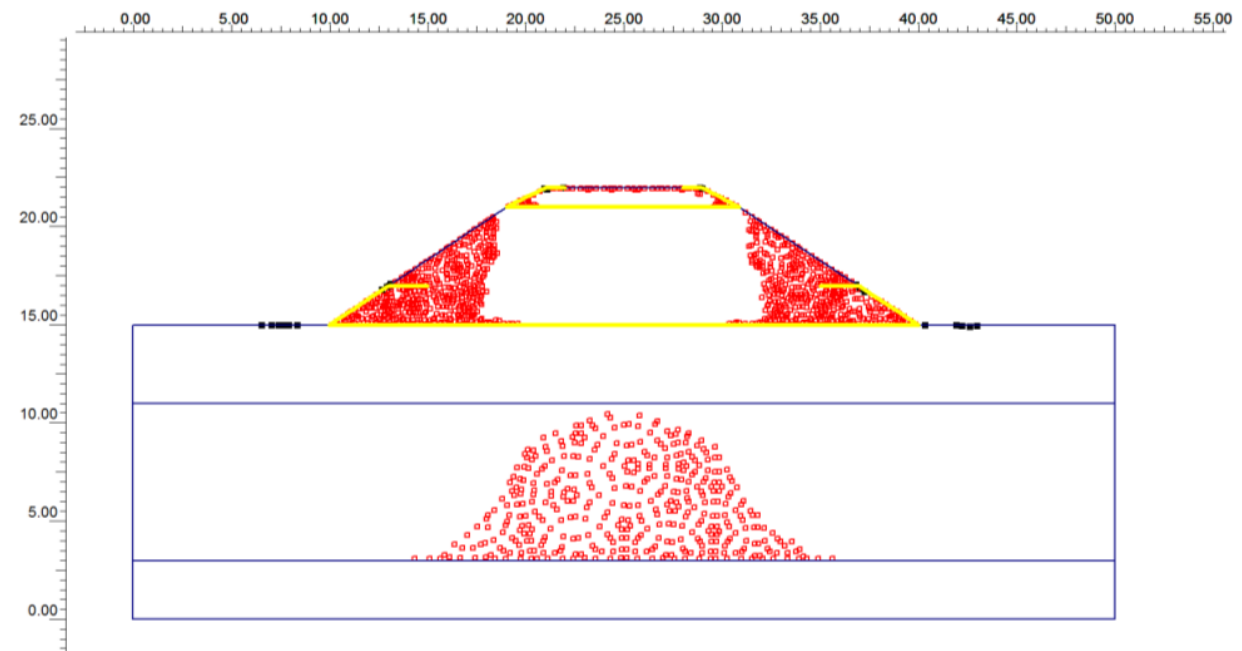

Fig. 9. Scheme of emerging plastic zones

When calculating the stability. Stability coefficient of 1.421 .

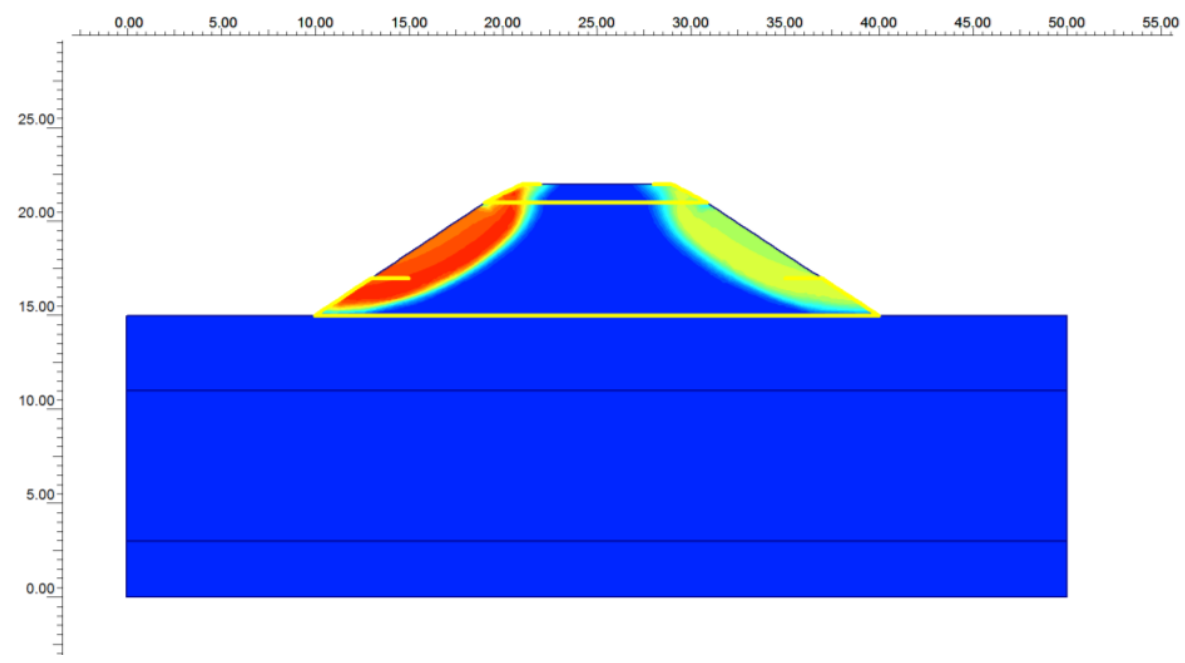

Fig. 10. General displacement

3 Case - reinforcing of the embankment slopes every $1 \mathrm{~m}$.

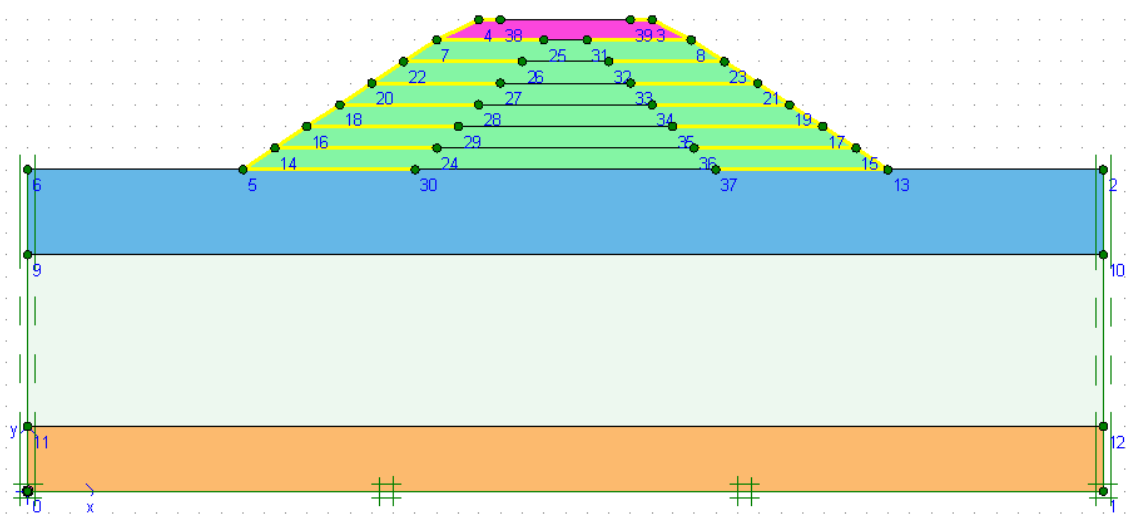

Fig. 11. Estimated scheme 


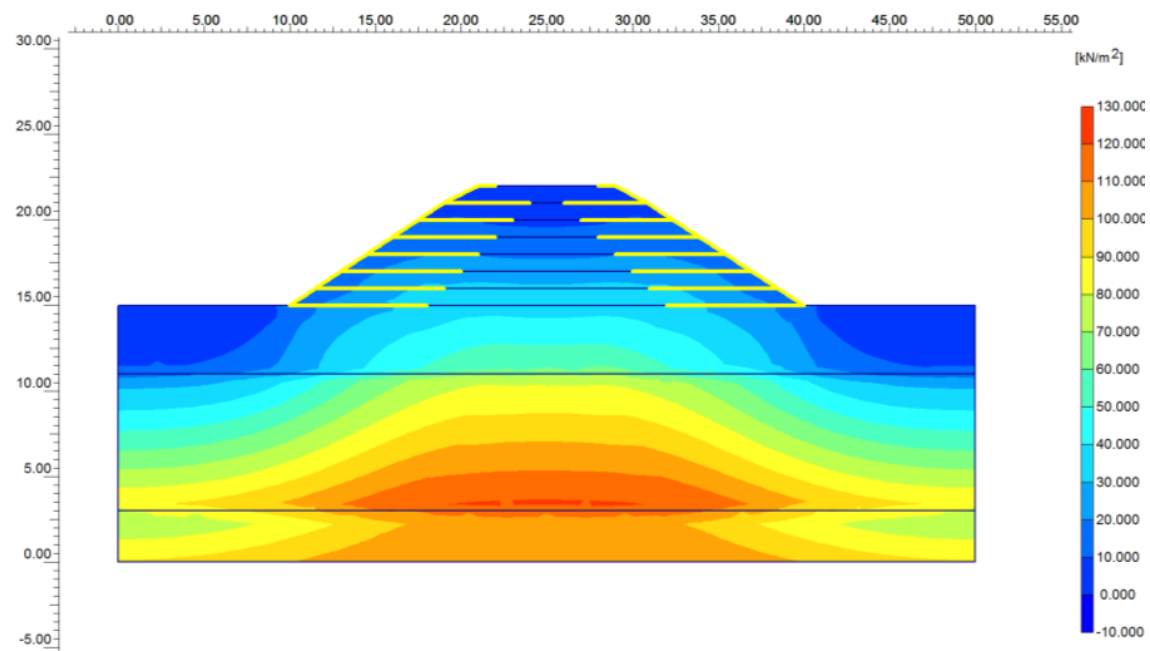

Fig. 12. Diagram full stresses

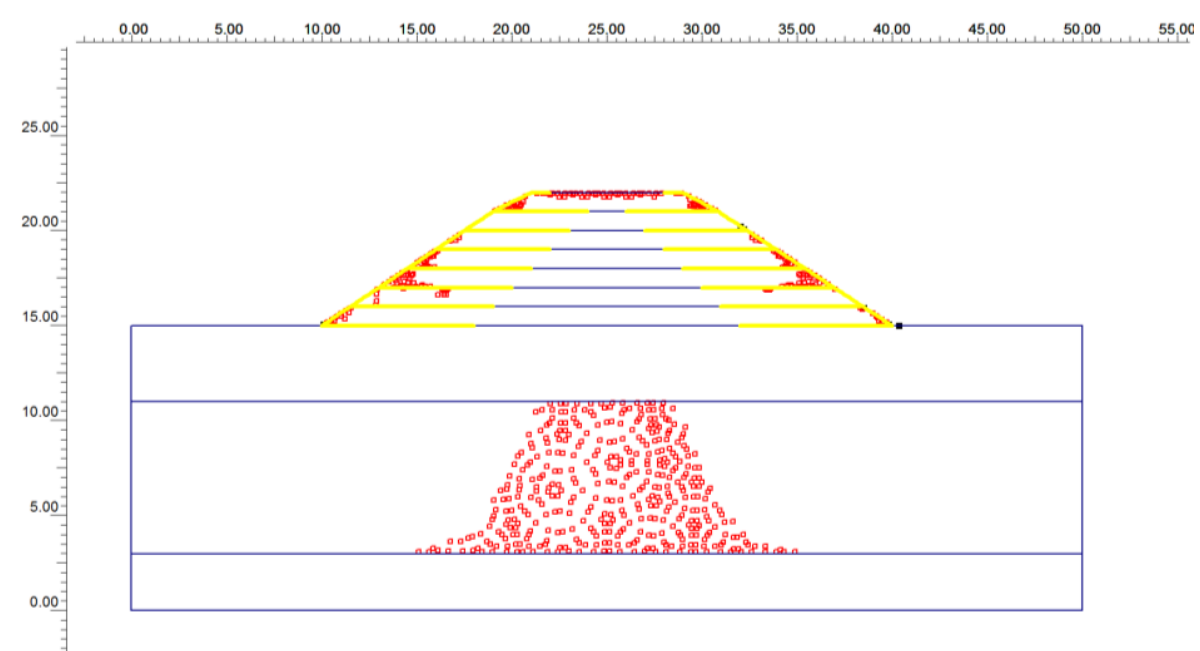

Fig. 13. Scheme of emerging plastic zones

When calculating the stability. The coefficient of stability is 1.594 .

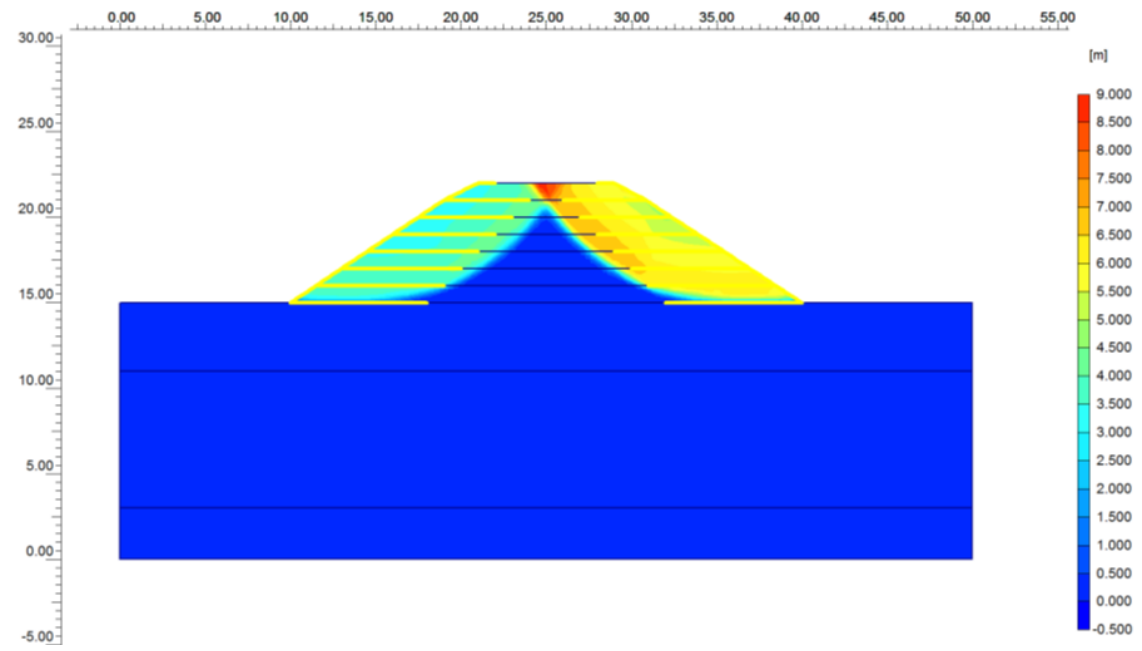

Fig. 14. General displacement

Results of calculations. When designing a bulk dam in order to increase the bearing capacity of the body of the embankment, geotextiles were used to reduce the volumes of the soil, which in this case performed the functions of reinforcement and strengthening of the design. 
Studies have been conducted in two stages. In the first stage, the stability of the bulk dike was considered at three laying of slopes 1:1, 1:1.5 and 1:2. The required stability coefficient is 1.46. Research results are presented in Table 1.

Table 1 - Technical and economic indicators of Stage 1 of research

\begin{tabular}{|l|c|c|c|}
\hline \multirow{2}{*}{ Settings settlements } & \multicolumn{3}{|c|}{ Laying of slopes } \\
\cline { 2 - 4 } & $1: 1$ & $1: 1.5$ & $1: 2$ \\
\hline Stability coefficient & 1.2 & 1.42 & 1.88 \\
\hline $\begin{array}{l}\text { The number of geotextile layers at } \\
\text { ks=1.46 }\end{array}$ & 5 & 5 & 4 \\
\hline The width of the bulk is lower, $\mathrm{m}$ & 24 & 31 & 38 \\
\hline The volume of soil is 100 p.m., $\mathrm{m}^{3}$ & 11900 & 14350 & 16800 \\
\hline
\end{tabular}

In the second stage, as a result of studies of the stress-deformed state of the bulk dam in the PLAXIS program, there are obtained the diagrams of full stresses, diagrams of horizontal and vertical displacements are obtained, the coefficients of the stability of the slope.

The main results are given in Table 2 .

Table 2 - Technical and economic indicators of the 2nd stage of research

\begin{tabular}{|l|c|c|c|}
\hline \multicolumn{1}{|c|}{ Settings settlements } & Embankment & $\begin{array}{c}\text { Embankments } \\
\text { with clips }\end{array}$ & $\begin{array}{c}\text { Funny with the } \\
\text { reinforcement of slopes }\end{array}$ \\
\hline General tension, $\mathrm{kPa}$ & 118.9 & 119.79 & 121.2 \\
\hline Vertical movements, mm & 0.145 & 0.067 & 0.0706 \\
\hline Horizontal movements, $\mathrm{mm}$ & 0.0104 & 0.00945 & 0.01731 \\
\hline Stability coefficient & 1.356 & 1.461 & 1.594 \\
\hline Geotextile, $100 \mathrm{~m}^{2}$ & - & 66 & 169 \\
\hline
\end{tabular}

Consequently, when using unclosed clamps in two rows, the smallest horizontal and vertical movements are obtained with almost identical overall stresses. In this case, the required value of the stability coefficient is received and the cost of geotextile materials is smaller than when arming the slopes of the embankment.

\section{Conclusions:}

1. The research data shows that when using geotextile, it is possible to reduce the laying of the slope. In this case, the volume of soil is reduced to $29 \%$, and the bearing capacity of the earth's embankment and redistribution of voltages arising in the soil array under the action of loads also increase.

2. The most optimal option for the technical and economic indicators was an option - a bulk dike with slots 1:1.5 with the reinforcement of embankments in two layers in the upper and lower parts.

\section{References}

[1] Rol' geotekstilya $\mathrm{v}$ dorozhnom stroitel'stve. [Online]. Available: https://stsgeo.ru/geotekstil/geotekstil_primenenie/geotekstil_v_dorozhnom_stroitelstve/ Accessed on: March 22, 2020.

[2] DBN V.2.3-4:2015. Sporudy transportu. Avtomobil'ni dorohy. Kyyiv, Minrehion Ukrayiny, 2015.

[3] DSTU B V.2.7-30:2013. Materialy nerudni dlya shchebenevykh i hraviynykh osnov ta pokryttiv avtomobil'nykh dorih. Tekhnichni umovy. Kyyiv, Minrehion Ukrayiny, 2013.

[4] VSN 49-86. Ukazaniya po povysheniyu nesushchey sposobnosti zemlyanogo polotna i dorozhnykh odezhd s primeneniyem sinteticheskikh materialov. Moskva «Transport».1988.

[5] V.I. Kleveko, "Issledovaniye raboty armirovannykh glinistykh osnovaniy", Vestnik Permskogo natsional'nogo issledovatel'skogo politekhnicheskogo universiteta. 
Stroitel'stvo i arkhitektura, no. 4, pp.101-110, 2014.

[6] A.L. Lanis, S.A. Ovchinnikov, "Usileniye gruntov zemlyanogo polotna armiruyushchimi konstruktsiyami", Trudy IX mezhdunarodnoy konferentsii "Sovremennyye problemy proyektirovaniya, stroitel'stva i ekspluatatsii zheleznodorozhnogo puti». Izd-vo MGUPS, 2012, pp. 11-113.

[7] A.L. Lanis, S.A. Ovchinnikov, "Vosstanovleniye ekspluatatsionnoy nadezhnosti zemlyanogo polotna dorog", Modernizatsiya i nauchnyye issledovaniya v transportnom komplekse. Pod red. Yushkova B.S. Perm': izd-vo Permskogo natsional'nogo issledovatel'skogo politekhnicheskogo universiteta, pp. 48-56, 2012.

[8] S.A. Ovchinnikov, "Ukrepleniye zemlyanogo polotna ob"yemnymi armiruyushchimi konstruktsiyami", Izvestiya transsiba, no. 3 (15), pp. 120-125, 2013.

[9] Sposob ukrepleniya otkosov zemlyanogo polotna: patent RU 2012112721. SGUPS; zayavl. 02.04.2012; resheniye o vydache patenta 26.09.2013.

[10] V.I. Kleveko, "Primeneniye geosinteticheskikh materialov v dorozhnom stroitel'stve v usloviyakh Permskogo kraya", Vestnik Permskogo natsional'nogo issledovatel'skogo politekhnicheskogo universiteta. Stroitel'stvo i arkhitektura, no. 1, pp. 114-123, 2013.

[11] D.G. Zolotozubov, V.I. Kleveko, A.B. Ponomarev, R.S. Nesterov, "Nekotoryye rezul'taty issledovaniy armogruntovykh osnovaniy", Aktual'nyye problemy geotekhniki: sb. st., posvyashchennyy 60-letiyu professora A.N. Bogomolova. VolgGASU, 2014, pp. 165-171.

[12] V.D. Sokolova, V.I. Kleveko, "Primeneniye metoda konechnykh elementov dlya modelirovaniya raboty pokrytiya gorodskoy ploshchadi iz bruschatki na armogruntovom osnovanii", Transport. Transportnyye sooruzheniya. Ekologiya, no. 4, pp. 77-89, 2014.

[13] N.I. Gorshkov, M.A. Krasnov, "Otsenka ustoychivosti gruntov armirovannykh sooruzheniy na osnove raschetov MKE", Dal'niy Vostok: Problemy razvitiya arkhitekturno-stroitel'nogo i dorozhno-stroitel'nogo kompleksa: materialy regional'noy nauchno-prakticheskoy konferentsii. Khabarovsk: Izd-vo Tikhookean. gos. un-ta, 2012, vol. 12, pp. 299-308.

[14] N.G. Bugaj, A.I. Krivonog, V.V. Krivonog, V.L. Fridrihson, "Gibkie krepleniya otkosov zemlyanyh gidrotekhnicheskikh sooruzheniy s ispol'zovaniyem geotekstilya", Prikladna gidromekhanika, Tom 8, no 1, pp. 3-15, 2006.

[15] Spravochnoye rukovodstvo PLAXIS. Versiya 8.

\title{
ДОСЛІДЖЕННЯ ВПЛИВУ ГЕОТЕКСТИЛЬНИХ МАТЕРІАЛІВ ПРИ БУДІВНИЦТВІ ДАМБ
}

\author{
${ }^{1}$ Слободяник Г.В., к.Т.н., \\ annaslobodyanik27@gmail.com, ORCID: 0000-0001-6437-0033 \\ ${ }^{1}$ Шокот К.3., магістр, \\ karina10023017@gmail.com, ORCID: 0000-0002-4316-4465 \\ ${ }^{1}$ Одеський наиіональний морський університет \\ вул. Мечнікова, 34, м. Одеса, 65029, Україна
}

Анотація. Одним з реальних і перспективних шляхів розширення номенклатури і видів конструкцій зміцнення укосів насипів і дамб $є$ використання геотекстильних матеріалів. У розглянутих конструкціях вони можуть виконувати захисні, фільтруючі, розділові, армуючі функції, при цьому покращують умови роботи грунту і шарів дорожнього одягу на узбіччях $\mathrm{i}$ в укісних частинах, підвищуючи їх стійкість. Застосування геотекстилю дає можливість розробити ефективні в техніко-економічному відношенні конструктивні рішення.

Як показав аналіз літературних даних, армування грунту є ефективним методом для збільшення несучої здатності основ при порівняно невеликих витратах. Тому дослідження як теоретичні, так i експериментальні, розробка і створення розрахункових моделей 3 урахуванням впливу армуючих елементів $є$ актуальною проблемою.

В роботі розглянуто напружено-деформований стан насипної дамби без геотекстилю та 3 двома варіантами його розташування. На основі проведеного чисельного моделювання

Bulletin of Odessa State Academy of Civil Engineering and Architecture, 2021, no. 83, page 112-121 
показано як при використанні геотекстилю підвищується несуча здатність споруди, при цьому зменшуються обсяги матеріалів. На другому етапі на основі проведених розрахунків вибрано оптимальний варіант розташування геотекстильного матеріалу в тілі споруди при найкращих техніко-економічних показниках.

Результати досліджень показують, що при армуванні насипу незамкнутими обоймами в два ряди - у верхній і нижній частині отримані найменші горизонтальні і вертикальні переміщення при майже однакових повних напруженнях. При цьому досягається необхідне значення коефіцієнта стійкості, зменшується обсяг грунту.

Таким чином, можна зробити висновки, що застосування геотекстильних матеріалів дозволяє скоротити витрати на основні будівельні матеріали при підвищенні експлуатаційних характеристик і продовження терміну служби споруди.

Ключові слова: насипна дамба, геотекстиль, армування грунту, стійкість укосів.

\section{ИССЛЕДОВАНИЕ ВЛИЯНИЯ ГЕОТЕКСТИЛЬНЫХ МАТЕРИАЛОВ ПРИ СТРОИТЕЛЬСТВЕ ДАМБ}

${ }^{1}$ Слободяник А.В., к.т.н., annaslobodyanik27@gmail.com, ORCID: 0000-0001-6437-0033

${ }^{1}$ Шокот К.3., магистр, karina10023017@gmail.com, ORCID: 0000-0002-4316-4465

${ }^{1}$ Одесский национальный морской университет ул. Мечникова, 34, м. Одесса, 65029, Украина

Аннотация. Одним из реальных и перспективных путей расширения номенклатуры и видов конструкций укрепления откосов насыпей и дамб является использование геотекстильных материалов. В рассматриваемых конструкциях они могут выполнять защитные, фильтрующие, разделительные, армирующие функции, при этом улучшают условия работы грунта и слоев дорожных одежд на обочинах и в откосных частях, повышая их устойчивость. Применение геотекстиля дает возможность разработать эффективные в технико-экономическом отношении конструктивные решения.

Как показал анализ литературных данных, армирование грунта является эффективным методом для увеличения несущей способности оснований при сравнительно небольших затратах. Поэтому исследования как теоретические, так и экспериментальные, разработка и создание расчетных моделей с учетом влияния армирующих элементов является актуальной проблемой.

В работе рассмотрено напряженно-деформированное состояние насыпной дамбы без геотекстиля и с двумя вариантами расположения геотекстиля. На основе проведенного численного моделирования показано как при использовании геотекстиля повышается несущая способность сооружения, при этом уменьшаются объемы материалов. На втором этапе на основе проведенных расчетов выбрано оптимальный вариант расположения геотекстильного материала в теле сооружения при наилучших технико-экономических показателях.

Результаты исследований показывают, что при армировании насыпи незамкнутыми обоймами в два ряда - в верхней и нижней части получены наименьшие горизонтальные и вертикальные перемещения при почти одинаковых полных напряжениях. При этом достигается необходимое значение коэффициента стойкости, уменьшается объем грунта.

Таким образом, можно сделать выводы, что применение геотекстильных материалов позволяет сократить затраты на основные строительные материалы при повышении эксплуатационных характеристик и продления срока службы сооружения.

Ключевые слова: насыпная дамба, геотекстиль, армирование грунта, устойчивость откосов.

Стаття надійшла до редакції 10.03.2021

Bulletin of Odessa State Academy of Civil Engineering and Architecture, 2021, no. 83, page 112-121 